\title{
Oxyurid nematodes of pet rodents in Slovakia - a neglected zoonotic threat
}

\author{
Nematódeos oxiurídeos de roedores de estimação na Eslováquia - uma \\ ameaça zoonótica negligenciada \\ Júlia Jarošová1* (D), Daniela Antolová1, Grzegorz Zalesny², Miloš Halán ${ }^{3}$ \\ ${ }^{1}$ Institute Parasitology SAS, Košice, Slovakia \\ ${ }^{2}$ Department of Invertebrate Systematics and Ecology, Wroclaw University of Environmental and Life Sciences, Wrocław, Poland \\ ${ }^{3}$ University of Veterinary Medicine and Pharmacy in Košice, Košice, Slovakia
}

How to cite: Jarošová J, Antolová D, Zalesny G, Halán M. Oxyurid nematodes of pet rodents in Slovakia - a neglected zoonotic threat. Braz J Vet Parasito/ 2020; 29(1): e014319. https://doi.org/10.1590/S1984-29612019072

\begin{abstract}
The role of rodents as reservoirs of helminths of public health importance is not well known. The zoonotic potential of Syphacia spp. has been confirmed; therefore, the study aimed to estimate the occurrence of oxyurid nematodes in small rodents from pet shops and breeding clubs in Slovakia. Fecal samples of 586 pet rodents kept in 133 cages were collected between 2016 and 2018 and examined by Faust's flotation method. Four species of oxyurid nematodes, Syphacia muris, S. obvelata, Aspiculuris tetraptera and Paraspidodera uncinata were detected. A. tetraptera was found in the faecal samples of all rodent species included in this survey. The number of positive boxes varied from $5.4 \%$ in hamsters to $70.0 \%$ with mice. The prevalence of Syphacia muris was highest in Mongolian gerbils where up to $75.0 \%$ boxes were positive; S. obvelata was found in $26.7 \%$ of boxes with mice, $25.0 \%$ of boxes with Mongolian gerbils and $3.2 \%$ of boxes with rats. The high prevalence of Syphacia spp. in all animal species points out the infection risk for humans. Animals offered for sale are often in close contact with human beings; therefore they should be regularly tested for parasites and then effectively dewormed.
\end{abstract}

Keywords: Oxyurid nematodes, Syphacia spp., Aspiculuris tetraptera, pet rodents.

\section{Resumo}

O papel dos roedores como reservatórios de helmintos de importância para a saúde pública não é bem conhecido. O potencial zoonótico de Syphacia spp. foi confirmado; portanto, o estudo teve como objetivo estimar a ocorrência de nematóides oxiurídeos em pequenos roedores de pet shops e clubes de reprodução na Eslováquia. Amostras fecais de 586 roedores mantidos em 133 gaiolas foram coletadas entre 2016 e 2018 e examinadas pelo método de flotação de Faust. Foram detectadas quatro espécies de nematódeos oxiurídeos, Syphacia muris, S. obvelata, Aspiculuris tetraptera e Paraspidodera uncinata, A. tetraptera foi encontrado nas amostras fecais de todas as espécies de roedores incluídas nesta pesquisa. O número de gaiolas positivas variou de 5,4\% em hamsters a 70,0\% em camundongos. A prevalência de Syphacia muris foi maior nos gerbilos da Mongólia, onde até 75,0\% das gaiolas foram positivas; S. obvelata foi encontrada em $26,7 \%$ das gaiolas com camundongos, $25,0 \%$ das gaiolas com gerbilos da Mongólia e 3,2\% das gaiolas com ratos. A alta prevalência de Syphacia spp. em todas as espécies animais aponta o risco de infecção para os seres humanos. Animais oferecidos para venda estão frequentemente em contato próximo com seres humanos; portanto, eles devem ser regularmente testados quanto a parasitas e, então, efetivamente desparasitados.

Palavras-chave: Nematódeos oxiurídeos, Syphacia spp., Aspiculuris tetraptera, roedores de estimação. 


\section{Introduction}

Rodents have increased in popularity as companion animals and are often purchased as the first pets for children due to their low cost and perceived ease of care. They are essential companions in many households, providing psychological, social and emotional benefits for both children and adults (BRYANT, 1990; KURNOŠOVA et al., 2019). Although pet rodents provide benefits to owners, they can also harbour a number of ecto and endo parasites, thus posing a threat to the health of the human beings who live in close proximity with them. While the presence of ectoparasites manifests in rodents by symptoms such as scratching, hair loss and skin changes, the light infection with intestinal parasites may not be manifested (ZAIN et al., 2012).

Pinworms belonging to family Oxyuridae are the most common intestinal helminths of domestic and laboratory rodents (ROBLES \& NAVONE, 2007; ABDEL-GABER, 2016). They are medium or small worms with three lips, no buccal capsule and an oesophagus with a well-defined single bulb at its posterior end (MALSAWMTLUANGI \& TANDON, 2009). Although rodent pinworms display some host-specificity, they can cross the species barrier. Due to their short prepatent periods, these parasites can be easily transmitted among rodents and rodent species held in the same cage (SÜRSAL et al., 2014). In general, Syphacia obvelata and Aspiculuris tetraptera are considered mouse parasites and Syphacia muris a rat pinworm (ABDEL-GABER \& FOL, 2015), but all three species were also reported in mice, rats, hamster and Mongolian gerbils (HUSSEY, 1957; ROSS et al., 1980; KELLOGG \& WAGNER, 1982; HENDRIX, 1998; BURR et al., 2012).

In animals, light infestation is usually subclinical, although high parasite loads can cause decreased activity, weight loss and occasionally also intestinal lesions, including rectal prolapse, intussusception, enteritis, rectal irritation with self-mutilation and faecal impaction (HEATLEY \& HARRIS, 2008; WHARY et al., 2015). In addition to the negative influence on the health of animals, the zoonotic potential of some members of the Oxyuridae family has also been confirmed. The first report on human infection with Syphacia obvelata appeared in 1919, when Riley (1919) identified the eggs and two mature females of the parasite in a child from Zamboanga, Philippines. In the same year, oxyurid eggs were reported in 429 cases among 140,000 soldiers examined in Texas, Oklahoma, New Mexico and Arizona, in the United States (KOFOID \& WHITE, 1919). Although the authors did not identify the parasite at that time, according to their morphological description Riley (1919) assumed that the aetiological agent of the infection was S. obvelata. In 1965, dr. E. C. Faust from Tulane University recorded the eggs of Syphacia muris in two children (STONE \& MANWELL, 1966), and later also Taylor et al. (2010) in laboratory technicians Furthermore, there are records of $S$. obvelata eggs being found in mummified human bodies from Nubia dated back to 700-300 years BC (HARTER, 2003). In 2009, Mahmoud et al. (2009) reported infection with Syphacia spp. in 25 (12.5\%) of 200 patients suffering from unexplained abdominal pain and eosinophilia. The worms were collected during a colonoscopy and identified by light microscopy and scanning electron microscope (SEM). The worms were identified as Syphacia muris and Syphacia spp., and Enterobius vermicularis was also detected in five children.

The study aimed at monitoring oxyurid nematodes in small rodents from pet shops and breeding clubs in Slovakia, which could enable an assessment of the risk of potential transmission of infection to their owners.

\section{Materials and Methods}

\section{Collection and examination of samples}

The faecal samples of 228 mice (Mus musculus domesticus), 165 rats (Rattus norvegicus), 119 hamsters (Mesocricetus auratus, Phodopus sungorus, Phodopus roborovskii, Phodopus campbelli, or mixtures of these species), 25 Mongolian gerbils (Meriones unguiculatus) and 
49 guinea pigs (Cavia porcellus) were collected from December 2016 to May 2018 from 12 pet shops and 3 breeding clubs in Banská Bystrica, Prešov, Poprad, Michalovce, Bardejov and Košice, Slovakia. The animals were housed in 133 separate boxes (cages) and the number of animals per box ranged from one to 26 . Pooled faecal samples were collected from the bottom of the box by tweezer (to separate the faecal pellets from the litter) and kept at room temperature until transported to the laboratory, where they were refrigerated at $+4^{\circ} \mathrm{C}$ before analysis. Subsequently, samples were analysed using a modified Faust's flotation method and detected eggs were identified according to morphological features (size, shape, etc.).

For organisational reasons (the need to house each animal separately for a few days) it was impossible to examine all rodents individually. Therefore, the positivity of animals was analysed according to "boxes" i.e. the positivity of faecal samples obtained from every box. The total number of animals in "positive" and "negative" boxes was also recorded.

All animals included in the survey were of unknown genetic background and age and had not received any previous antiparasitic treatment prior to enrolment. The research was complied with all the relevant national regulations and institutional policies for the care and use of animals.

\section{Prevalence data}

For each helminth species two values of apparent prevalence were estimated; the first was expressed as the number of positive boxes/overall number of boxes, and second as the number of animals in positive boxes/overall number of animals in boxes. Each prevalence value was provided with a Jeffreys Confidence Interval estimated in package prevalence implemented into R software (DEVLEESSCHAUWER et al., 2015). Next, the Bayesian estimation of the true prevalence from apparent prevalence was obtained by testing the pooled samples (DEVLEESSCHAUWER et al., 2015).

\section{Results}

In total, 586 animals kept in 133 cages were examined within the study, and the nematodes Syphacia spp., Aspiculuris tetraptera and Paraspidodera uncinata were detected (Table 1, Figure 1). The most prevalent nematodes were Aspiculuris tetraptera and Syphacia muris, which were found in the faecal samples of all rodent species included in this survey. The number of boxes in which Aspiculuris tetraptera was detected varied from $5.4 \%$ in hamsters to $70.0 \%$ of boxes with mice. Syphacia muris was detected less frequently, and its prevalence was highest in Mongolian gerbils where up to $75.0 \%$ of boxes were positive. S. obvelata was found in $26.7 \%$ of boxes with mice, $25.0 \%$ of boxes with Mongolian gerbils and $3.2 \%$ of boxes with rats. Paraspidodera uncinata was found in only one box (3.7\%) with two guinea pigs, and this parasite species was not detected in any other animal species (Table 1). 
Table 1. Oxyurid nematodes in pet rodents.

\begin{tabular}{|c|c|c|c|c|c|c|c|c|c|c|c|c|}
\hline \multirow[b]{2}{*}{ Species } & \multirow[b]{2}{*}{$n$} & \multirow[b]{2}{*}{$\begin{array}{l}\text { No. of } \\
\text { boxes }\end{array}$} & \multicolumn{2}{|c|}{ Syphacia muris } & \multicolumn{2}{|c|}{ Syphacia obvelata } & \multicolumn{2}{|c|}{ Aspiculuris tetraptera } & \multicolumn{2}{|c|}{$\begin{array}{c}\text { Paraspidodera } \\
\text { uncinata }\end{array}$} & \multicolumn{2}{|c|}{ Total } \\
\hline & & & $\begin{array}{c}\text { No. of } \\
\text { positive } \\
\text { boxes/\% } \\
(95 \% \mathrm{Cl})\end{array}$ & $\begin{array}{c}\text { No. of } \\
\text { animals } \\
\text { in pos. } \\
\text { boxes/\% } \\
(95 \% \mathrm{Cl})\end{array}$ & $\begin{array}{c}\text { No. of } \\
\text { positive } \\
\text { boxes /\% } \\
(95 \% \mathrm{Cl})\end{array}$ & $\begin{array}{c}\text { No. of } \\
\text { animals } \\
\text { in pos. } \\
\text { boxes/\% } \\
(95 \% \mathrm{Cl})\end{array}$ & $\begin{array}{c}\text { No. of } \\
\text { positive } \\
\text { boxes /\% } \\
(95 \% \mathrm{Cl})\end{array}$ & $\begin{array}{c}\text { No. of } \\
\text { animals } \\
\text { in pos. } \\
\text { boxes/\% } \\
(95 \% \mathrm{Cl})\end{array}$ & $\begin{array}{c}\text { No. of } \\
\text { positive } \\
\text { boxes/\% } \\
(95 \% \mathrm{Cl})\end{array}$ & $\begin{array}{c}\text { No. of } \\
\text { animals } \\
\text { in pos. } \\
\text { boxes/\% } \\
((95 \% \mathrm{Cl})\end{array}$ & $\begin{array}{c}\text { No. of } \\
\text { positive } \\
\text { boxes } / \% \\
(95 \% \mathrm{Cl})\end{array}$ & $\begin{array}{c}\text { No. of } \\
\text { animals } \\
\text { in pos. } \\
\text { boxes/\% } \\
(95 \% \mathrm{Cl})\end{array}$ \\
\hline Rat & 165 & 31 & $\begin{array}{c}6 / 19.3 \% \\
(8.5-35.6)\end{array}$ & $\begin{array}{c}38 / 23.0 \% \\
(17.1-29.9)\end{array}$ & $\begin{array}{c}1 / 3.2 \% \\
(0.3-14.1)\end{array}$ & $\begin{array}{c}1 / 0.6 \% \\
(0.01-2.8)\end{array}$ & $\begin{array}{c}4 / 12.9 \% \\
(4.5-27.8)\end{array}$ & $\begin{array}{l}22 / 13.3 \% \\
(8.8-19.1)\end{array}$ & (0) & $\begin{array}{c}0 / 0 \% \\
(0)\end{array}$ & $\begin{array}{c}10 / 32.3 \% \\
(17.9-49.7)\end{array}$ & $\begin{array}{c}55 / 33.3 \% \\
\text { (26.1-40.7) }\end{array}$ \\
\hline Mouse & 228 & 30 & $\begin{array}{c}10 / 33.3 \% \\
(18.6-51.1)\end{array}$ & $\begin{array}{c}78 / 34.2 \% \\
(28.3-40.5)\end{array}$ & $\begin{array}{c}8 / 26.6 \% \\
(13.5-44.1)\end{array}$ & $\begin{array}{c}81 / 35.5 \% \\
(29.5-41.9)\end{array}$ & $\begin{array}{c}21 / 70.0 \% \\
(52.3-84.0)\end{array}$ & $\begin{array}{l}161 / 70.6 \% \\
(64.5-76.2)\end{array}$ & $\begin{array}{c}0 / 0 \% \\
(0)\end{array}$ & $\begin{array}{c}0 / 0 \% \\
(0)\end{array}$ & $\begin{array}{c}29 / 96.7 \% \\
\text { (85.4-99.6) }\end{array}$ & $\begin{array}{l}226 / 99.1 \% \\
(97.2-99.8)\end{array}$ \\
\hline Hamster & 119 & 37 & $\begin{array}{c}8 / 21.6 \% \\
(10.8-36.7)\end{array}$ & $\begin{array}{c}37 / 31.1 \% \\
(23.3-39.8)\end{array}$ & $\begin{array}{l}0 / 0 \% \\
(0)\end{array}$ & $\begin{array}{c}0 / 0 \% \\
(0)\end{array}$ & $\begin{array}{c}2 / 5.4 \% \\
(1.1-16.2)\end{array}$ & $\begin{array}{c}4 / 3.4 \% \\
(1.1-7.8)\end{array}$ & $\begin{array}{c}0 / 0 \% \\
(0)\end{array}$ & $\begin{array}{l}0 / 0 \% \\
(0)\end{array}$ & $\begin{array}{c}10 / 27.0 \% \\
(14.8-42.6)\end{array}$ & $\begin{array}{c}41 / 34.5 \% \\
\text { (26.3-43.3) }\end{array}$ \\
\hline $\begin{array}{l}\text { Mongolian } \\
\text { gerbil }\end{array}$ & 25 & 8 & $\begin{array}{c}6 / 75.0 \% \\
(40.8-94.4)\end{array}$ & $\begin{array}{c}21 / 84.0 \% \\
(66.3-94.3)\end{array}$ & $\begin{array}{c}2 / 25 \% \\
(5.6-59.1)\end{array}$ & $\begin{array}{c}7 / 28.0 \% \\
(13.5-47.3)\end{array}$ & $\begin{array}{c}1 / 12.5 \% \\
(1.3-45.4)\end{array}$ & $\begin{array}{c}3 / 12.0 \% \\
(3.5-28.7)\end{array}$ & $\begin{array}{c}0 / 0 \% \\
(0)\end{array}$ & $\begin{array}{c}0 / 0 \% \\
(0)\end{array}$ & $\begin{array}{c}7 / 87.5 \% \\
(54.6-98.6)\end{array}$ & $\begin{array}{c}24 / 96.0 \% \\
(82.8-99.6)\end{array}$ \\
\hline Guinea pig & 49 & 27 & $\begin{array}{c}1 / 3.7 \% \\
(0.04-16.0)\end{array}$ & $\begin{array}{c}2 / 4.1 \% \\
(0.8-12.4)\end{array}$ & $\begin{array}{c}0 / 0 \% \\
(0)\end{array}$ & $\begin{array}{c}0 / 0 \% \\
(0)\end{array}$ & $\begin{array}{c}2 / 7.4 \% \\
(1.6-21.7)\end{array}$ & $\begin{array}{c}5 / 10.2 \% \\
(4.0-20.9)\end{array}$ & $\begin{array}{c}1 / 3.7 \% \\
(0.4-16.0)\end{array}$ & $\begin{array}{c}2 / 4.1 \% \\
(0.8-12.4)\end{array}$ & $\begin{array}{c}3 / 11.1 \% \\
(3.2-26.7)\end{array}$ & $\begin{array}{c}7 / 14.3 \% \\
(6.6-26.0)\end{array}$ \\
\hline Total & 586 & 133 & $\begin{array}{c}25 / 18.8 \% \\
(12.9-26.1)\end{array}$ & $\begin{array}{l}176 / 30.0 \% \\
(26.4-33.8)\end{array}$ & $\begin{array}{c}11 / 8.3 \% \\
(4.5-13.8) \\
\end{array}$ & $\begin{array}{c}89 / 15.2 \% \\
(12.5-18.3)\end{array}$ & $\begin{array}{c}30 / 22.5 \% \\
(16.1-30.2) \\
\end{array}$ & $\begin{array}{c}195 / 33.3 \\
(29.5-37.2)\end{array}$ & $\begin{array}{c}1 / 0.7 \\
(0.1-3.4) \\
\end{array}$ & $\begin{array}{c}2 / 0.3 \% \\
(0.1-1.1)\end{array}$ & $\begin{array}{c}59 / 44.4 \% \\
(36.1-52.8)\end{array}$ & $\begin{array}{l}353 / 60.2 \% \\
(56.2-64.2\end{array}$ \\
\hline
\end{tabular}

$n$ - total number of animals; $95 \% \mathrm{Cl}-95 \%$ confidence interval.

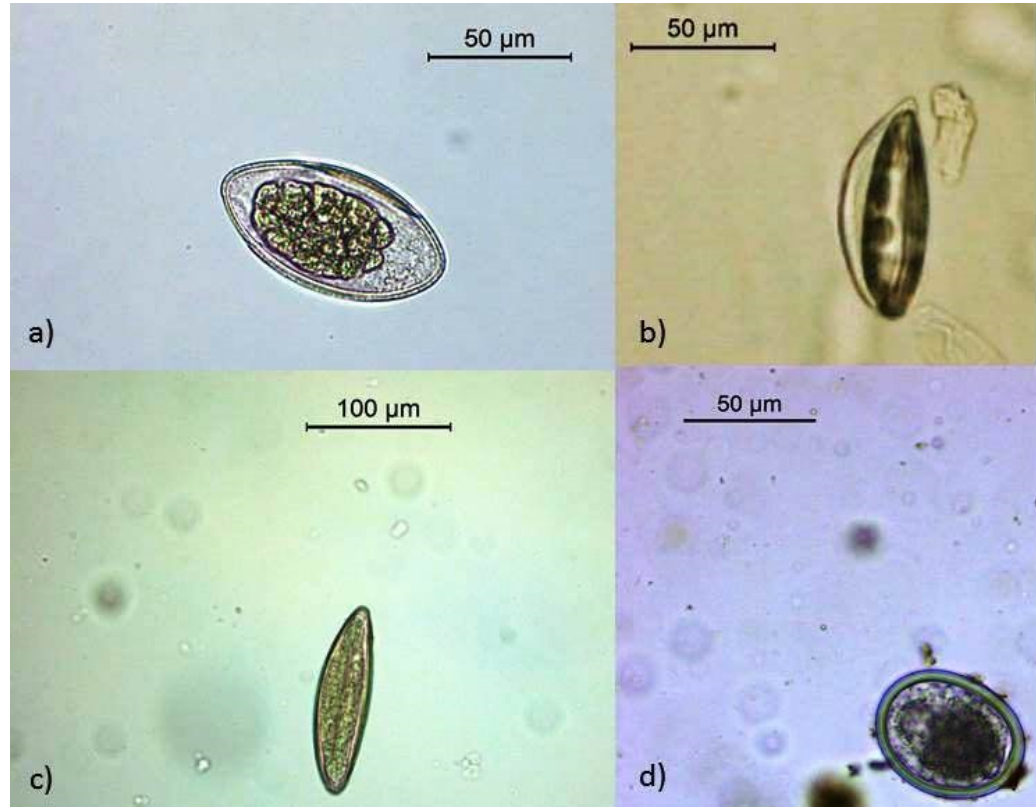

Figure 1. Eggs of oxyurid nematodes found in rodenst form pet shops and breeding clubs in Slovakia: (a) Aspiculuris tetraptera; (b) Syphacia muris (c); Syphacia obvelata; (d) Paraspidodera uncinata.

In our study we provided two prevalence values, which, due to lack of possibility of testing the animals individually, could be biased by false positive results. The prevalence was estimated as the ratio of positive boxes to overall number of boxes or the ratio of the number of animals in positive boxes to the overall number of animals.

Our methodology was based on the direct life cycle of the parasites recorded in this survey and coprophagia, a characteristic nutritional behaviour of the involved rodent species. Therefore, we can assume that most animals living in the same cage could be infected with the same parasitic species. Based on this fact, $71.8 \%$ animals could suffer from parasitic infection. Nevertheless, we estimated the prevalence using Bayesian 
estimation for pooled samples, indicating that even the minimal values of prevalence (not including the behaviour of the host or life cycle of the parasites) achieved high values. Based on these analyses, the true prevalence of $S$. muris in individual animals ranged from $4.0 \%$ in guinea pigs to $46.0 \%$ in Mongolian gerbils. S. obvelata also occurred most often in Mongolian gerbils (12.5\%). A. tetraptera dominated in mice (15.9\%) and was less frequent in Mongolian gerbils (7.6\%), guinea pigs (6.1\%) and rats (3.2\%) (Table 2).

Table 2. Bayesian estimation of true prevalence of oxyurid nematodes.

\begin{tabular}{|c|c|c|c|c|}
\hline Species & $\begin{array}{c}\text { Syphacia muris } \\
\text { (\%) } \\
(95 \% \mathrm{Cl})\end{array}$ & $\begin{array}{c}\text { Syphacia obvelata } \\
\text { (\%) } \\
(95 \% \mathrm{Cl})\end{array}$ & $\begin{array}{c}\text { Aspiculuris } \\
\text { tetraptera (\%) } \\
(95 \% \mathrm{Cl})\end{array}$ & $\begin{array}{c}\text { Paraspidodera } \\
\text { uncinata } \\
\text { (\%) } \\
(95 \% \mathrm{Cl})\end{array}$ \\
\hline Rat & $\begin{array}{c}4.7 \\
(2.0-8.6)\end{array}$ & $\begin{array}{c}1.2 \\
(0.1-3.3)\end{array}$ & $\begin{array}{c}3.2 \\
(1.1-6.3)\end{array}$ & $\begin{array}{l}0.0 \\
(0)\end{array}$ \\
\hline Mouse & $\begin{array}{c}5.7 \\
(2.9-9.4)\end{array}$ & $\begin{array}{c}4.8 \\
(2.2-8.3)\end{array}$ & 15.9 & $\begin{array}{l}0.0 \\
(0)\end{array}$ \\
\hline Hamster & $\begin{array}{c}8.7 \\
(4.2-15.0)\end{array}$ & $\begin{array}{l}0.0 \\
(0)\end{array}$ & $\begin{array}{c}2.5 \\
(0.5-5.8)\end{array}$ & $\begin{array}{l}0.0 \\
(0)\end{array}$ \\
\hline $\begin{array}{l}\text { Mongolian } \\
\text { gerbil }\end{array}$ & $\begin{array}{c}46.0 \\
(21.1-74.6)\end{array}$ & $\begin{array}{c}12.3 \\
(2.7-27.8)\end{array}$ & $\begin{array}{c}7.6 \\
(1.0-20.1)\end{array}$ & $\begin{array}{l}0.0 \\
(0)\end{array}$ \\
\hline Guinea pig & $\begin{array}{c}4.0 \\
(0.5-11.2)\end{array}$ & $\begin{array}{l}0.0 \\
(0)\end{array}$ & $\begin{array}{c}6.1 \\
(1.3-14.1)\end{array}$ & $\begin{array}{c}3.9 \\
(0.5-10.5)\end{array}$ \\
\hline
\end{tabular}

$95 \% \mathrm{Cl}-95 \%$ confidence interval.

When analysing the total prevalence of oxyurids in different animal species, the most often infected species was mouse. Oxyurid eggs were present in $96.7 \%$ of boxes in which $99.1 \%$ of all the mice were kept. High positivity was also recorded in Mongolian gerbils, with $87.5 \%$ of boxes containing parasite eggs. Rats, hamsters and guinea pigs were infected less frequently, with oxyurid egg detected in $32.3 \%, 27.0 \%$ and $11.1 \%$ of boxes, respectively.

\section{Discussion}

Rodents are known to carry microbial human pathogens, but their role as reservoir hosts for helminths of public health importance is less known. Within the study performed on small rodents from pet shops and breeding clubs in Slovakia, four species of oxyurid nematodes, namely Syphacia obvelata, S. muris, Aspiculuris tetraptera and Paraspidodera uncinata were detected.

In rats, hamsters and Mongolian gerbils the most prevalent parasite was Syphacia muris, the common rat pinworm. The percentage of boxes positive for this species ranged from $19.3 \%$ in rats to $75.0 \%$ in Mongolian gerbils. S. muris was also detected in boxes with mice and guinea pigs, but it was not the predominant parasite in these species. It is an oxyurid nematode with a short direct life cycle, not longer than seven or eight days. The eggs are deposited by the female on the perianal area or in the colon, where they embryonate within several hours. Apart from the usual oral mode of infection, retroinfection is also common. Parasitic infestation does not usually result in clinical signs and is generally considered to be non-pathogenic (TAFFS, 1976), but heavy infestations can be associated with mucoid enteritis, and abscesses or granulomas containing pinworms or their eggs are occasionally found in the mesenteric lymph nodes at necropsy (BLAIR et al., 1968).

Syphacia obvelata was recorded less frequently, its typical elongated banana-shaped eggs were found only in three rodent species: mice, Mongolian gerbils and rats. S. obvelata is considered a ubiquitous parasite of wild and laboratory mice, but rats, 
gerbils and hamsters, as well as humans are also occasionally infected (ABDEL-GABER, 2016). Eggs of S. obvelata, similarly to S. muris, are deposited on perianal region of the host and become infective within several hours.

In mice, the most prevalent parasitic species was Aspiculuris tetraptera, which occurred in $70.0 \%$ of boxes. Its adult worms can penetrate the colonic wall and cause granulomas (MULLINK, 1970). The life cycle is direct and takes approximately 23-25 days. Mature females inhabit the large intestine, where they survive from 45 to 50 days and lay their eggs. The eggs are deposited at night and are excreted in a mucous layer, covering faecal pellets. They embryonate in the environment, where they require $6-7$ days at $24^{\circ} \mathrm{C}$ to become infective and, subsequently, can survive for weeks (WHARY et al., 2015).

The fourth oxyurid nematode found in the study was the Paraspidodera uncinata recorded in only 1 (3.7\%) box with two guinea pigs. It is a non-pathogenic nematode of guinea pigs that can be found in caecal contents or in the mucosa of the caecum and colon. Occasionally, very heavy infections may cause diarrhoea and weight loss. The life cycle of this parasite is direct, and it is transmitted through feed and water contaminated with infective eggs. P. uncinata is not considered a public health hazard (HENDRIX, 1998).

In the study, mice were the most often infested animal species: parasite eggs were not detected in only one box with two mice. Mongolian gerbils also seem to be often infected, with $87.5 \%$ of boxes, in which $96.0 \%$ animals were kept, showing a positive result. Guinea pigs could be considered the animals with the best parasitic status, as oxyurid eggs were present in only three (11.1\%) boxes with a total of 7 animals.

Our research demonstrates that parasitic infections occur quite often in rodents in pet shops and breeding clubs. However, there are only limited data related to parasites of rodents in pet shops from abroad. Polozowski et al. (2016) observed a 6\% prevalence of Syphacia spp. in hamsters in pet shops in Wroclaw, Poland. In Germany, the prevalence of Syphacia spp. in pet shop stored mice was 57.1\% (DAMMANN et al., 2011). In Turkey, the parasitic infection rate found in pet shops reached $57.5 \%$ in dwarf hamsters and $54.9 \%$ in Syrian hamsters. The prevalence of Syphacia spp. in Syrian hamsters was $11 \%$ and Aspiculuris spp. 5.6\% (SÜRSAL et al., 2014). In the study of Panti-May et al. (2017) the overall prevalence of helminths in pet rodents in the city of Mérida, Mexico, was $61.2 \%$. In mice the prevalence of $S$. obvelata was $78.3 \%$ and A. tetraptera was $60.9 \%$. S. muris was found only in rats with a prevalence of $17.4 \%$. Direct examination of intestinal contents of 18 mice from pet shops in New York revealed Syphacia obvelata in 7 mice and Aspiculuris tetraptera in one animal (ROBLE et al., 2012). In Japan, Hayashimoto et al. (2015) reported Aspiculuris tetraptera and Syphacia obvelata in $28.5 \%$ out of 28 examined mice.

Although in presented study it was impossible to examine all animals individually, it can be assumed that individuals kept in one box would be infected with the same parasitic species. This is connected mainly with the short life cycle of the parasites found in this survey and coprophagia, a characteristic nutritional behaviour of rodents that allows the recovery of nutrients that were not utilized during the first passage through the digestive system. Such a suggestion was also confirmed by the survey of Sürsal et al. (2014), who found that all animals that lived in the same cage were infected with Syphacia spp. and Aspiculuris spp. The hygiene level in the organisation that breeds and keeps animals has a great impact on the spread of parasites. The life cycle of Syphacia spp. is very short, with enhances its spread between animals. On the other hand, the eggs of A. tetraptera need 6 - 7 days to become infective; therefore, the high infection rate of this parasite recorded in the study suggests a low frequency of litter changing, with intervals longer than 7 days, or insufficient cleaning of boxes during the litter change. Thus, our results suggest a low hygiene level in breeding clubs and pet shops and/or in their suppliers in Slovakia. Oxyurid parasites also occurred quite frequently in surveys performed in Poland, Germany, Turkey, Mexico, the USA and Japan (DAMMANN et al., 2011; ROBLE et al., 2012; SÜRSAL et al., 2014; HAYASHIMOTO et al., 2015; 
POLOZOWSKI et al., 2016; PANTI-MAY et al., 2017), which clearly indicates that the issue of insufficient hygiene is a more pressing problem globally.

Treatment of oxyurid infection includes administration of anthelminthic drugs topically or in drinking water or feed. Several anthelmintics were recommended, including ivermectine, fenbendazole and piperazine (JURÁŠEK \& DUBINSKÝ, 1993; SKOPETS et al., 1996). Oral administration of ivermectine in drinking water (dosage: $8 \mathrm{mg} / \mathrm{L}$ water) though effective can have side effects and affect the breeding performance of animals, therefore topical administration of $0.1 \%$ solution $(1-2 \mathrm{ml}$ per cage) is regarded as a safer choice (SUETA et al., 2002; HRAPKIEWICZ et al., 2013). Fenbendazol is administered orally ( $20 \mathrm{mg} / \mathrm{kg}$, every $24 \mathrm{~h}$ for 5 days), but it can be also applied in drinking water $(70 \mathrm{mg} / \mathrm{L})$ or feed $(150 \mathrm{mg} / \mathrm{kg})$ for 3 cycles based upon a week on-off schedule. Piperazine is recommended to be applied in combination with ivermectin as $2.1 \mathrm{mg} / \mathrm{ml}$ piperazine sulphate solution in water for two weeks followed by $0.007 \mathrm{mg} / \mathrm{ml}$ ivermectin in third and fourth week (ZENNER, 1998; HRAPKIEWICZ et al., 2013; CHAWLA et al., 2015).

To prevent the spread of infection, the high level of sanitation and disinfection, control of all newly purchased animals, rigorous implementation of quarantine measures and regular tests for parasites in rodents intended for sale, accompanied by effective deworming are important.

The high prevalence rate of Syphacia spp. in all the examined animal species also points out the infection risk for humans. As mentioned in the introduction, several authors have confirmed the zoonotic potential of S. muris and S. obvelata. Moreover, the eggs of S. muris are similar to those of E. vermicularis. Although S. muris ova are larger 72-82 $\times 25-36 \mu \mathrm{m}$ than those of E. vermicularis (50-60 x 20-30 $\mu \mathrm{m}$ ) (BAKER, 2007; GENCHI et al., 2019) it is possible that especially less experienced investigators can sometimes erroneously misdiagnose as S. muris as E. vermicularis, as reported Stone \& Manwell (1966).

The possibility of misdiagnosis could also be increased by the fact that the zoonotic character of Syphacia spp. is not generally known. Therefore, it is not considered to be the cause of human infection during routine diagnostics.

To conclude, relatively high occurrence of oxyurid nematodes in pet rodents from pet shops and breeding clubs was recorded in the study. As the animals offered for sale are often in close contact with human beings, the infestation with zoonotic parasites presents infection risk, especially with children. Moreover, the same animal species obtained from different breeders and put together in same cage constitute a risk of transmission of infection among animals. Therefore, the risk of infecting humans should not be neglected, and animals should be regularly tested for parasites and then effectively treated if found be positive.

\section{Acknowledgements}

The work financially supported by the Research \& Development Operational Program funded by ERDF "Environmental protection against parasitozoonoses under the influence of global climate and social changes", code ITMS 26220220116 (1.0).

\section{References}

Abdel-Gaber R, Fol M. Aspicularis tetrapetra (Nematode, Heteroxynematidae) of laboratory mice Mus musculus (Rodentia, Muridae): a potential risk of zoonotic infection for researchers. Cienc Tec Vitivinic 2015; 30(8): 125-136.

Abdel-Gaber R. Syphacia obvelata (Nematode, Oxyuridae) infecting laboratory mice Mus musculus (Rodentia, Muridae): phylogeny and host-parasite relationship. Parasitol Res 2016; 115(3): 975985. http://dx.doi.org/10.1007/s00436-015-4825-0. PMid:26581371.

Baker DG. Flynn's parasites of laboratory animals. 2nd ed. Oxford: Blackwell Publishing; 2007. 813 p. http://dx.doi.org/10.1002/9780470344552. 
Blair LS, Thompson PE, Vandenbelt JM. Effects of pyrvinium pamoate in the ration or drinking water of mice against pinworms Syphacia obvelata and Aspiculuris tetraptera. Lab Anim Care 1968; 18(3): 314-327. PMid:4233364.

Bryant B. The richness of child-pet relationship: a consideration of both benefits and costs of pets to children. Anthrozoos 1990; 3(4): 253-261. http://dx.doi.org/10.2752/089279390787057469.

Burr HN, Paluch LR, Roble GS, Lipman NS. Parasitic diseases. In: Suckow MA, Stevens KA, Wilson RP, editors. The laboratory rabbit, guinea pig, hamster, and other rodents. Waltham: Academic Press; 2012. p. 839-866. http://dx.doi.org/10.1016/B978-0-12-380920-9.00032-8.

Chawla S, Jena S, Prusty B. Different treatment regimen for eradication of pinworm (Syphacia obvelata) infection in mice colony. J Anim Res 2015; 5(2): 321-324.

Dammann P, Hilken G, Hueber B, Köhl W, Bappert MT, Mähler M. Infectious microorganisms in mice (Mus musculus) purchased from commercial pet shops in Germany. Lab Anim 2011; 45(4): 271 275. http://dx.doi.org/10.1258/la.2011.010183. PMid:21508117.

Devleesschauwer B, Torgerson P, Charlier J, Levecke B, Praet N, Roelandt S, et al. Prevalence: tools for prevalence assessment studies. R package version 0.4.0 [online]. 2015 [cited 2019 August 7]. Available from: https://cran.r-project.org/web/packages/prevalence/index.html

Genchi M, Potters I, Kaminsky RG, Montresor A, Magnino S. Bench aids for the diagnosis of intestinal parasites. 2nd ed. Geneva: WHO; 2019. 33 p.

Harter S. Implication de la paléoparasitologie dans l'étude des populations anciennes de la vallée du nil et du Proche-orient: études de cas [dissertation]. Reims: Université de Reims ChampagneArdenne; 2003.

Hayashimoto N, Morita H, Ishida T, Uchida R, Tanaka M, Ozawa M, et al. Microbiological survey of mice (Mus musculus) purchased from commercial pet shops in Kanagawa and Tokyo, Japan. Exp Anim 2015; 64(2): 155-160. http://dx.doi.org/10.1538/expanim.14-0087. PMid:25502736.

Heatley JJ, Harris MC. Hamsters and gerbils. In: Michell M, Tully TN. Manual of exotic pet practice. USA: Saunders Elsevier; 2008. p. 406-432.

Hendrix CHM. Diagnostic veterinary parasitology. 2nd ed. St. Louis: Mosby; 1998.

Hrapkiewicz K, Colby L, Denison P. Clinical laboratory animal medicine: an introduction. 4th ed. New Jersey: Wiley Blackwell; 2013. 431 p.

Hussey K. Syphacia muris vs. S. obvelata in laboratory rats and mice. J Parasitol 1957; 43(5): 555-559. http://dx.doi.org/10.2307/3274477. PMid:13476307.

Jurášek V, Dubinský P. Veterinary parasitology. Bratislava: Príroda; 1993. 382 p.

Kellogg HS, Wagner JE. Experimental transmission of Syphacia obvelata among mice, rats, hamsters, and gerbils. Lab Anim Sci 1982; 32(5): 500-501. PMid:6890603.

Kofoid CA, White AW. A new nematode infection of man. JAMA 1919; 72(8): 567-579. http://dx.doi.org/10.1001/jama.1919.02610080033010.

Kurnošova OP, Arisov MV, Odoyevskaya IM. Intestinal parasites of pets and other house-kept animals in Moscow. Helminthologia 2019; 56(2): 108-117. http://dx.doi.org/10.2478/helm-2019-0007.

Mahmoud AE, Attia RAH, Eldeek HEM, Abdel Baki L, Oshaish HA. Oxyurid nematodes detected by colonoscopy in patients with unexplained abdominal pain. Parasitol United J 2009; 2: 93-102.

Malsawmtluangi C, Tandon V. Helminth parasite spectrum in rodent hosts from bamboo growing areas of Mizoram, north-east India. J Parasit Dis 2009; 33(1-2): 28-35. http://dx.doi.org/10.1007/s12639-009-0004-5. PMid:23129885.

Mullink JW. Pathological effects of oxyuriasis in the laboratory mouse. Lab Anim 1970; 4(2): 197-201. http://dx.doi.org/10.1258/002367770781071699. PMid:5535889.

Panti-May JA, Caraveo-Centeno L, Hernández-Betancourt SF, Robles MDR, Machain-Williams C. Survey of intestinal helminths collected from pet rodents in México. Parasitol Res 2017; 116(11): 3239-3242. http://dx.doi.org/10.1007/s00436-017-5626-4.

Polozowski A, Piasecki T, Kowalska M, Klimiuk M, Hormańska M. Prevalence of internal parasites on hamsters in pet shops in Wroclaw. Annals Parasitol 2016; 62(Suppl): 127.

Riley WA. A Mouse Oxyurid, Syphacia obvelata, as a parasite of man. J Parasitol 1919; 6(2): 89-93. http://dx.doi.org/10.2307/3270899. 
Roble GS, Gillespie V, Lipman NS. Infectious disease survey of Mus musculus from pet stores in New York City. J Am Assoc Lab Anim Sci 2012; 51(1): 37-41. PMid:22330866.

Robles MR, Navone GT. A new species of Syphacia (Nematoda: Oxyuridae) from Oligoryzomys nigripes (Rodentia: Cricetidae) in Argentina. Parasitol Res 2007; 101(4): 1069-1075. http://dx.doi.org/10.1007/s00436-007-0595-7. PMid:17541641.

Ross CR, Wagner JE, Wightman SR, Dill SE. Experimental transmission of Syphacia muris among rats, mice, hamsters and gerbils. Lab Anim Sci 1980; 30(1): 35-37. PMid:7190628.

Skopets B, Wilson RP, Griffith JW, Lang CM. Ivermectin toxicity in young mice. Lab Anim Sci 1996; 46(1): 111-112. PMid:8699806.

Stone WB, Manwell RD. Potential helminth infections in humans from pet or laboratory mice and hamsters. Public Health Rep 1966; 81(7): 647-653. http://dx.doi.org/10.2307/4592796. PMid:19316507.

Sueta T, Miyosh I, Okamura T, Kasai N. Experimental eradication of pinworms (Syphacia obvelata and Aspiculuris tetraptera) from mice colonies using ivermectin. Exp Anim 2002; 51(4): 367-373. http://dx.doi.org/10.1538/expanim.51.367. PMid:12221930.

Sürsal N, Gökpinar S, Yildiz K. Prevalence of intestinal parasites in hamsters and rabbits in some pet shops of turkey. Turkiye Parazitol Derg 2014; 38(2): 102-105. http://dx.doi.org/10.5152/tpd.2014.3338. PMid:25016116.

Taffs LF. Pinworm infections in laboratory rodents. Lab Anim 1976; 10(1): 1-13. http://dx.doi.org/10.1258/002367776780948862. PMid:768631.

Taylor MA, Coop RL, Wall RL. Parasitologia veterinária. 3rd ed. Rio de Janeiro: Guanabara Koogan; 2010.

Whary MT, Baumgarth N, Fox JG, Barthold SW. Biology and diseases of mice. In: Fox J, Anderson L, Otto G, Pritchett-Corning K, Whary M. Laboratory animal medicine. 3rd ed. USA: Academic Press; 2015. p. 124-125. http://dx.doi.org/10.1016/B978-0-12-409527-4.00003-1.

Zain SNM, Behnke JM, Lewis JW. Helminth communities from two urban rat populations in Kuala Lumpur, Malaysia. Parasit Vectors 2012; 5(1): 47. http://dx.doi.org/10.1186/1756-3305-5-47. PMid:22397763.

Zenner L. Effective eradication of pinworms (Syphacia muris, Syphacia obvelata and Aspiculuris tetraptera) from a rodent breeding colony by oral anthelmintic therapy. Lab Anim 1998; 32(3): 337-342. http://dx.doi.org/10.1258/002367798780559202. PMid:9718483. 